\title{
Implementation of the EU ecological flow policy in Italy with a focus on Sardinia
}

\author{
Davide Moccia ${ }^{1 *}$ Luca Salvadori, ${ }^{2}$ Simone Ferrari, ${ }^{2}$ Alessandra Carucci, ${ }^{2}$ Antonio Pusceddu ${ }^{1}$ \\ ${ }^{1}$ Department of Life and Environmental Sciences, University of Cagliari, Via Tommaso Fiorelli 1, 09126 Cagliari; ${ }^{2}$ Department of \\ Civil-Environmental Engineering and Architecture, University of Cagliari, Via Tommaso Fiorelli 1, 09126 Cagliari, Italy
}

\begin{abstract}
River ecosystems are characterised by a naturally high level of hydrodynamic perturbations which create aquatic-terrestrial habitats indispensable for many species, as well as for the human beings' welfare. Environmental degradation and habitat loss caused by increasing anthropogenic pressures and global change affect freshwater aquatic ecosystems worldwide and have caused changes in water flow regimes and channels morphologies. These, in turn, decreased the natural flow capacity and reduced habitat availability, thus causing severe degradation of rivers' ecological integrity. The ecological flow (e-flow) is commonly intended as the quantity, timing, duration, frequency and quality of water flows required to sustain freshwater, estuarine and near shore ecosystems and the human livelihoods and well being. Maintaining the e-flow represents a potential tool for restoring and managing river ecosystems, to preserve the autochthonous living communities, along with environmental services and cultural/societal values. In the last decade, methods for the determination of the e-flow in European rivers moved from a simply hydrological approach towards establishing a linkage between the hydrological regime and the good ecological status (GES) of the water bodies, as identified by the European Water Framework Directive (WFD; 2000/60/EC). Each Member State is required to implement and integrate into the River Basin Management Plans (RBMP) a methodology for the determination of the e-flow, ensuring that rivers can achieve and maintain the GES. The competent river basin authorities have thus to ascertain whether national methodologies can be applied to different river typologies and basin environment characteristics. In this context, we narratively review the e-flow assessments in the heterogeneous Italian territory, in particular on a water scant region such as Sardinia, by analysing laws, guidelines and focusing on study cases conducted with micro and meso-scale hydraulic-habitat approaches. In the sight of a more ecological-based application of national e-flow policy, we suggest that meso-habitat methods provide a valuable tool to overcome several limitations of current e-flow implementation in the Italian territory. However, to face future challenges, such as climate change adaptation, we stress the need for further experimental studies to update water management plans with greater attention for nature conservation.
\end{abstract}

\section{INTRODUCTION}

The functioning of riverine ecosystems is the result of complex interactions among multiple abiotic and biotic components which, altogether, contribute to the establishment of specific and dynamic mosaics of aquatic and terrestrial habitats. The variability of flows in terms of magnitude, frequency, duration, timing and rate of change, controls river ecosystem functioning, by preserving their integrity and allowing the persistence of native species and natural habitats, as well as the development of the human society (Poff et al., 1997; Bunn and Arthington, 2002; Acreman, 2016).

Nowadays, the increasing intensification of human activities is the primary factor of rivers natural flow regimes alteration (Peñas et al., 2016; Horne et al., 2017). As a consequence of a growing human population and associated economic development, many anthropogenic interventions have led to significant degradation of more than $60 \%$ of the world's rivers (Nilsson et al., 2005). Global water withdrawals increase by about $10 \%$ every 10 years, with this rate being much higher in developing regions (Organisation for Economic Co-operation and Development, 2012). The exploitation of water resources for urban, agricultural and industrial purposes, together with changes in land use, transport and energy production negatively affects both the hydrology (reduced residual water) and the morphology of rivers (longitudinal and lateral connectivity interruption) (Lake, 2007; Döll et al., 2009). In parallel, climate change is also influencing rivers' flow regime (Barnett et al., 2005; Blöschl et al., 2017; Pletterbauer et al., 2018). Indeed, the outflow of rivers is directly influenced by long-term changes in both precipitation and temperature trends (Dudgeon et al., 2006). Variations in the amount of precipitations associated with global change can modify the hydrological cycles, which in turn, influence habitats availability for many aquatic organisms (Filipe et al., 2013). Temperature variations affect the timing of the outflow and modify the chemical-physical features of the aquatic environment, ultimately altering ecological and biological processes (Pletterbauer et al., 2018). Furthermore, climate change can cause a deep modification of human usages of rivers' water or directly interact with human pressures. For instance, in many regions of the world, due to the increasing water scarcity, a growing number of water management measures, such as impoundments, diversion weirs and dams, are being adopted, contributing significantly to lowering rivers' habitats quality (Postel, 1998; Magilligan et al., 2005; Zhang et al., 2015).

A well-established approach aimed to preserve freshwater ecosystems and river ecological status relies on the definition of a sustainable environmental flow 
release from dams and other types of derivation (Acreman et al., 2016). The environmental flow (e-flow) is commonly intended as the quantity, timing, duration, frequency and quality of water flows required to sustain freshwater, estuarine and near shore ecosystems and the human livelihoods and well being (Tharme, 2000). The concept of e-flow has been discussed for more than 40 years (Tharme, 2003; Acreman and Dunbar, 2004; King and Brown, 2006; Poff and Matthews, 2013; Acreman, 2016) and it is now worldwide recognized by several national and regional water protection policies, e.g. the European Water Framework Directive (European Commission, 2015), the South African National Water Act (Forslund et al., 2009) and the Brisbane Declaration (Arthington et al., 2018). Many countries have incorporated e-flow provisions as they have updated water policy and laws (Le Quesne et al., 2010). Over the last few years, there has been a growing consensus about the need of science-based approaches and requirements for the assessment of e-flows in order to achieve successful management of freshwater ecosystems, conciliating natural habitats conservation with the supply of freshwater for human usage (Acreman and Dunbar, 2004). The achievement of such a trade-off can become more critical in the sights of modified hydrological conditions that will result as a consequence of current climate change (Tonkin et al., 2019).

Tharme (2003) identified $>200$ methods to assess the water requirements of aquatic species and habitats, and support e-flows management practices to achieve both ecological and social targets (see also Acreman and Dunbar 2004). However, to date, there are still several limiting factors for the implementation of successful eflow policy, due, mainly, to limitations in institutional capacity, scientific knowledge and monitoring resources. These have been summarized by Le Quesne et al., (2010) in four crucial issues:

i) the scarcity of knowledge about sites and speciesspecific e-flows requirements;

ii) the lack of political decision and effort to recognizing a need to maintain sufficient water in rivers and wetland systems;

iii) imperfect understanding of the practical issues and costs of implementation to achieve the e-flow regime;

iv) the lack of a design and maintenance of robust monitoring systems to assess the ecological and other outcomes of environmental watering in an adaptive management framework.

In order to overcome these general issues, research and monitoring of e-flows' adjustments is often required (Richter, 2009; Zang et al., 2012), as well as, the synthesizing of knowledge and experience gained from individual case studies (Arthington et al., 2004; Poff et al., 2010). In fact, regional and local approaches have a fundamental role in the understanding e-flow methods limitations. They will be crucial for the implementation of an applicable methodology to define e-flows by River Basin Authorities. This is particularly needed in a context where heterogeneous climatic regions (e.g. Alpine, Mediterranean) occur and a homogeneous and more ecological-based methodology for the definition of the eflow is requested. In this context, we review the status of e-flow implementation in Italy, with a focus on a region with high water scarcity such as Sardinia, by analyzing laws, guidelines and study cases conducted with hydraulic-habitat approaches, both at micro and mesoscale. The final aim of this review is to highlight current challenges and limitation that make difficult the application and adaptation of a common e-flows methodology and give cues for the selection of a suitable habitat simulation models that could be integrated to overcome these limits.

\section{THE EUROPEAN GUIDANCE ON E-FLOWS}

Nowadays, in Europe, the most significant pressures causing failure to achieve the Good Ecological Status (GES) are the hydro-morphological ones (affecting ca. 40 $\%$ of surface water bodies, with the highest proportion reported for rivers and transitional waters) (E.E.A. Report n. 7/2018). The largest proportion (26\%) of water bodies is affected by physical alterations in the channel, bed, riparian zone, whereas up to $24 \%$ of the investigated water bodies are affected by the presence of structures, such as dams/barriers and locks, that alter the rivers' longitudinal continuity (E.E.A. Report n. 7/2018).

Since 2012, to implement e-flows management in the River Basin Management Plans the European Commission (EC) has asked the Member States (MSs) to focus on pressures affecting the hydrological status of water bodies (Schmidt and Benítez Sanz, 2012). However, the lack of harmonized methodologies and, consequently, of sufficient or sufficiently consistent data for the definition of e-flows' assessment by each MS has raised several operational and interpretation difficulties (Acreman and Ferguson, 2010). For this reason, in 2015, the EC released the e-flow Guidance Document (Ecological flows in the implementation of the Water Framework Directive; WFD CIS Guidance Document No. 31). In this document, the definition of e-flow is provided within the context of the Water Framework Directive (WFD) as "a hydrological regime consistent with the achievement of the environmental objectives of the WFD in natural surface water bodies as mentioned in Article 4(1)" and is interpreted as the "amount of water required for the aquatic ecosystem to continue to thrive and provide the services we rely upon". Once terminology has been clarified, concern has then arisen on how to 
calculate e-flows in different environmental contexts. The document did not report a full protocol for the implementation of e-flows nor led to a uniform e-flow implementation strategy, instead encouraged MSs to share the knowledge obtained so far to evaluate site-specific eflows implementation conditions (specific environmental values or ecosystem services) and to promote the e-flow definition in the WFD planning process, not considering it as a separate problem.

In the guidance document, the e-flow quantification methods are provided and classified in three major categories (Hydrological, Hydraulic-habitat and Holistic methodologies, Table 1), also according to costeffectiveness, time-efficiency, complexity and focus (Dyson et al., 2003; Tharme, 2003; Arthington et al., 2004; Richter et al., 2006; King et al., 2008).

Hydrological methods are based on the analysis of the natural flow regimes derived from historical streamflow data (mean annual flows, monthly flows, high/low flows or more complex hydrological indices) that can be existing or simulated. These methods provide an overall baseline flow that aims to conserve the natural flow integrity of a stream and maintain native habitat and species. Hydrological methods are still the most widely used approaches (European Commission, 2015) and, often, are considered as initial analyses in the preliminary phases for supporting more complex methods. However, pure hydrology-based methodologies for e-flows assessment incompletely capture habitat dynamics and ecological responses of aquatic and riparian fauna. These methods fail to account for flow interactions with the channel morphology and its variation in space or modifications over time. Furthermore, in the absence or lack of streamflow gauging stations, hydrological modelling of streamflow data series requires quite a lot of expertise, can be time-consuming and may produce significant uncertainties when predicting magnitude, frequency and timing of extreme events (low and high flows).

Hydraulic/Habitat simulation methods are more sophisticated approaches in which habitat availability for aquatic species and their vital stages are expressed as a combination of hydro-morphological features and their ecological preferences. Habitat modelling software such as TELEMAC (Galland, 1991), PHABSIM (USGS, 2001), RHYHABSIM (Jowett, 2010), CASiMiR (Schneider et al., 2010) and RIVER 2D (Steffler and Blackburn, 2002) allow this type of accurate site and species characterisation at the micro-scale, while MesoHABSIM (Parasiewicz, 2001, 2007), MesoCASiMIR (Schneider et al., 2001) and RHM (Maddock et al., 2001) at the meso-scale. Hydraulichabitat methods are often considered more accurate than hydrological ones since they complement them by incorporating flow-dependent and morphology-dependent ecological data, such as the occurrence of wetted areas and the connectivity between them, local hydrodynamic conditions of depth and flow velocity, sediment distribution and composition, and the presence of shelters and refuges for the fauna. However, they may require a considerable amount of fieldwork and expertise to collect the hydro morphological and biological data for model calibration.

Holistic methods are based on a global vision of the riverine ecosystem and encompass all major components or attributes of the river system. These methods require multidisciplinary inputs from different river scientists that integrate data, model predictions and expert knowledge (Tharme, 1996; Arthington, 1998; Tharme, 2000; King et al., 2008). They consider both spatial and temporal

Table 1. List of e-flow approaches and methodologies in different countries and contexts.

\begin{tabular}{|c|c|c|}
\hline Approach & Method & Source \\
\hline Hydrological & $\begin{array}{l}\text { Tennant (Montana) } \\
\text { Aquatic Base Flow } \\
\text { Median Monthly Flow } \\
\text { Range of Variability Approach } \\
\text { Sustainability Boundary Approach and Presumptive }\end{array}$ & $\begin{array}{l}\text { Tennant (1976) } \\
\text { Caissie and El-Jabi (1995) } \\
\text { Caissie and El-Jabi (1995) } \\
\text { Ritcher } \text { et al. }(1997) \\
\text { Ritcher } \text { et al. }(1997 ; 2011)\end{array}$ \\
\hline $\begin{array}{l}\text { Hydraulic/Habitat simulation } \\
\text { (modelling) methods }\end{array}$ & $\begin{array}{l}\text { PHABSIM (Physical HABitat SIMulation) } \\
\text { MesoHABSIM } \\
\text { EVHA (Evaluation de Habitat) } \\
\text { RSS (River System Simulator) } \\
\text { CASIMIR (Computer Aided SIMulation of habitat in Regulated streams) } \\
\text { River 2D } \\
\text { MesoCASIMIR }\end{array}$ & $\begin{array}{l}\text { Bovee (1982) } \\
\text { Parasiewicz (2001) } \\
\text { Ginot (1995) } \\
\text { Alfredsen } \text { et al. (1995) } \\
\text { Jorde (2006) } \\
\text { Blackburn and Steffler (2003) } \\
\text { Eisner } \text { et al. (2005) }\end{array}$ \\
\hline Holistic frameworks & $\begin{array}{l}\text { Generalized Habitat models (e.g. STATHAB) } \\
\text { Building Block Method (BBM) } \\
\text { DRIFT (Downstream Response to Imposed Flow Transformation) } \\
\text { Benchmarking } \\
\text { ELOHA }\end{array}$ & $\begin{array}{l}\text { Lamouroux and Jowett } \\
\text { Tharme and King (1998) } \\
\text { King et al. (2003) } \\
\text { Arthington (1998; et al., 2006) } \\
\text { Poff et al. (2010) }\end{array}$ \\
\hline
\end{tabular}


variations, allowing stakeholders and decision-makers to establish an acceptable risk as a balance among ecological goals, economic costs and scientific uncertainties. Two different main categories of holistic methods exist: bottomup approaches, i.e. the Building Block Methodology (King and Louw, 1998), and top-down approaches, i.e. DRIFT (Downstream Response to Imposed Flow Transformation, King et al., 2003) and ELOHA (Ecological Limits of Hydrological Alteration; Poff et al., 2010), that define eflows in terms of acceptable degrees of departure from the natural (or another reference state) flow regime and, therefore, require accurate quantification of ecological response to stress.

To integrate the methodologies described above and to define a stepwise approach, the European e-flows framework, following the global trends, indicates three study levels:

i) a preliminary risk analysis to define water bodies at risk of not achieving the WFD objectives because of hydrological alteration;

ii) the establishment of an extensive hydrological monitoring network able to provide a good data collection in different water release situations to improve the usage of hydrological/habitat approaches in advanced steps of the analysis;

iii) once the results of the experimental analysis are elaborated, the determination of a water-body typespecific environmental flow assessment (EFA), together with an assessment of the gap between current and reference state (gap analysis), to guide specific measures.

\section{E-FLOW ASSESSMENT IN ITALY}

The Italian territory overlooks the Mediterranean Sea and is characterised by a complex geo-morphological structure, with $51 \%$ of the country dominated by high mountains chains (the Alps and the Apennines), 29\% covered by hills, and $20 \%$ occupied by plains (Surian et al., 2003). Such heterogeneous geo-morphological system interacts with the variability of the atmospheric circulation patterns making this Mediterranean region one of the most vulnerable to future climate change (Surian et al., 2003; Giorgi, 2006). Recent studies have predicted an increase in mean temperature of around 1.5$2.0^{\circ} \mathrm{C}$ in all seasons until 2050 (Tomozeiu et al., 2017), together with an expected slight decrease of the mean annual rainfalls, and an intensification of extreme rainfall events (Brunetti et al., 2001; Giorgi and Lionello, 2008; Coppola and Giorgi, 2010; Lionello et al., 2012). Additionally, scientific literature tends to agree that in spring and summer, change in the climate patterns is predicted to cause an increase in the frequency and intensity of droughts (Spinoni et al., 2017).
In this context, water demand is continuously increasing to satisfy the growing socio-economic needs and justified the construction of a significant number of large reservoirs in the Italian territory, placing Italy in the fifth place among the European member states with the highest number of dams (542, ICOLD, 2007). Additionally, in the last century, most of the Italian rivers have experienced a considerable morphological change in terms of bed-level lowering (commonly of the order of 3-4 m), channel narrowing (in some cases up to 50\%) and changes in channel pattern, due to sediment extraction, weirs and channelization (Surian et al., 2003). Such increasing impacts caused by these hydromorphologic pressures, coupled with the current climate change, have led to significant alteration of the hydrology of Italian rivers, with consequent spatial and temporal reduction of fluvial habitats, accompanied by a decline of the environmental status and biodiversity loss (Dudgeon et al., 2006; Feyen et al., 2009; Carlisle et al. 2010; Filipe et al., 2013; Blöschl et al., 2017; De Girolamo et al., 2017; Horne et al., 2017; Spinoni et al., 2017).

In 1989, with the enactment of the Italian Law n.183, the hydrological regime relevance was recognized by the Italian Government, which established the first legal act, including the qualitative definition of the e-flow. The concept of e-flow was initially associated to the idea of a "minimum constant flow" to be guaranteed in riverbeds, to promote a balance between human needs and the natural requirements of the riverine ecosystem (Law 183/1989). The Ministerial Guidelines for the definition of the e-flow were issued only in 2004, and the subsequent Legislative Decree n.152/2006 introduced the concept of "Minimum Vital Flow" (hereafter MVF), as the instant outflow needed to be preserved in downstream water diversions in order to conserve the physical (morphological, hydrological and hydraulic), physicalchemical (water quality) and biological features of natural riverine ecosystems.

To date, the general formulas adopted among the Italian Districts by the River Basin Authorities, are based on simple hydrological formulas, mostly considering the percentage of mean annual or monthly flow, corrected through several coefficients taking into account different environmental aspects (Table 2). These formulas are the most exploited in Italy for their ease of application and cheapness. However, although this was the first step towards the implementation of a national rule to determinate the e-flow, three main problematic elements emerged: i) the absence of a univocal rule regarding the determination of the key hydrological parameters (e.g., annual average flow, the average flow of a specified period, the average flow of specific months); ii) the presence of significant diversity among calculation 
formulas resulting in territorial values of MVF notably heterogeneous, even within the same river basin district (when the rivers pass through different regions); iii) the absence of an evident and robust correlation between the MVF values and the environmental status of the water bodies classified by the indices required by Legislative

Table 2. List of formulas adopted in different Italian regions for assessing the Minimal Vital Flow (MVF) in Basin Managements Plans (2015-2021).

\begin{tabular}{|c|c|c|}
\hline Regions & Formula & Legend \\
\hline Po & $\mathrm{MVF}=\mathrm{k} \times$ qmeda $\times \mathrm{S} \times \mathrm{M} \times \mathrm{Z} \times \mathrm{A} \times \mathrm{T}$ & $\begin{array}{l}\text { k: Experimental parameter determined for individual } \\
\text { hydrographical areas }\end{array}$ \\
\hline Piemonte & & $\begin{array}{l}\text { qmeda: specific annual average flow per unit of area of the } \\
\text { basin (in } 1 / \mathrm{s} \mathrm{km}^{2} \text { ) }\end{array}$ \\
\hline Liguria & & S: surface of the natural catchment area $(\mathrm{Kmq})$ \\
\hline Toscana & & M: morphologic parameter \\
\hline Valle d'Aosta & & Z: greater $(\mathrm{N}, \mathrm{F}, \mathrm{Q})$ \\
\hline Emilia Romagna & & $\begin{array}{l}\mathrm{N} \text { : coefficient of naturalness } \\
\text { F: coefficient of fruition } \\
\text { Q: parameter concerning the quality of river water } \\
\text { A: parameter concerning the interaction between surface waters } \\
\text { and groundwater } \\
\text { R: monthly hydrological modulation (class) } \\
\text { T: time flow modulation. }\end{array}$ \\
\hline Marche & $\begin{array}{l}\mathrm{MVF}(\text { monthly })=[(\mathrm{K} 0-2,24 \times 10-5 \times \mathrm{S})] \times \mathrm{Qm}) \times \\
(\mathrm{M} \times \mathrm{Z} \times \mathrm{A} \times \mathrm{T})\end{array}$ & $\begin{array}{l}\text { K0: } 0,075 \\
\text { S: surface of the natural catchment area } \\
\text { Qm: average annual natural flow regime in the considered section } \\
\text { M: morphologic parameter } \\
\text { Z: greater }(\mathrm{N}, \mathrm{F}, \mathrm{Q}) \\
\mathrm{N} \text { : current naturalness } \\
\text { F: fruition parameter } \\
\text { Q: parameter concerning the quality of river water } \\
\text { A: parameter concerning the interaction between surface waters } \\
\text { and groundwater } \\
\text { T: time flow modulation. }\end{array}$ \\
\hline $\begin{array}{l}\text { Provincia Autonoma } \\
\text { di Trento }\end{array}$ & $\operatorname{MVF}($ monthly $)=\operatorname{MVF} \times \mathrm{SUP} \times \mathrm{S} \times \mathrm{P} \times \mathrm{A} \times \mathrm{G} \times \mathrm{PE} \times \mathrm{R}$ & $\begin{array}{l}\text { SUP: absolute surface of the natural catchment area } \\
\text { S: surface of the natural catchment area } \\
\text { P: monthly precipitations } \\
\text { A: average altitude of the catchment area } \\
\text { PE: basin and riverbed permeability } \\
\text { G: riverbed geomorphology }\end{array}$ \\
\hline Veneto & $\mathrm{MVF}=\left[\left(\mathrm{K}_{\text {biol }}\right)+\mathrm{K}_{\text {nat }}\right) \times 207 \times \mathrm{S} 0,8 \times$ qmedia $\times 10-6$ & $\begin{array}{l}\text { R: monthly hydrological modulation (class) } \\
\mathrm{K}_{\text {biol }} \text { index of biological criticality } \\
\mathrm{K}_{\text {nat }}: \text { criticality naturalness Index } \\
\mathrm{S} \text { surface of the natural catchment area }\left(\mathrm{Km}^{2}\right) \\
\text { qmedia: average annual flow }\left(1 / \mathrm{sm}^{2}\right)\end{array}$ \\
\hline Friuli Venezia Giulia & $\mathrm{QMVF}=\mathrm{K} \times \mathrm{T} \times \mathrm{P} \times \mathrm{M} \times \mathrm{Q}_{\text {media }}$ & $\begin{array}{l}\mathrm{Q}_{\text {media }} \text { : average annual flow to the section concerned } \\
\mathrm{K} \text { : protection level } \\
\text { T: timing coefficient } \\
\mathrm{P} \text { : coefficient of naturalness and tourism } \\
\text { M: coefficient of seasonal modulation }\end{array}$ \\
\hline Abruzzo & $\begin{array}{l}\mathrm{MVF}=\mathrm{Q} \times \mathrm{K}_{\text {biol }}=\left(\mathrm{K} 1 \times \mathrm{Q}_{\text {rusc }}+\mathrm{K} 2 \times \mathrm{Q}_{\text {acqm }}+\mathrm{K} 3 \times\right. \\
\left.\mathrm{Q}_{\text {sorg }}\right) \times\left(\mathrm{K}_{\text {iif }}+\mathrm{K}_{\text {morf }}+\mathrm{K}_{\text {i.B. } . E .}+\mathrm{K}_{\text {morf }}\right)\end{array}$ & $\begin{array}{l}\mathrm{Q}_{\text {russ: }} \text { : runoff flow } \\
\mathrm{Q}_{\text {acqm }}: \text { flow due to the emergence of minor aquifers } \\
\mathrm{Q}_{\text {sorg: }} \text { : flow due to the emergence of significant groundwater } \\
\text { bodies } \\
\mathrm{K} 1, \mathrm{~K} 2, \mathrm{~K} 3 \text { are three coefficients that allow to weigh } \\
\text { independently the contribution of each of the flow components } \\
\text { defined above } \\
\mathrm{K}_{\text {iff: }}: \text { coefficient fluvial functional } \\
\mathrm{K}_{\text {morf }}: \text { morphologic coefficient } \\
\mathrm{K}_{\text {itt: }}: \text { ichthyofauna coefficient }\end{array}$ \\
\hline Sicily & $\mathrm{MVF}=10 \%\left(\mathrm{Q}_{\mathrm{med}}\right)$ & $\mathrm{Q}_{\text {med }}:$ average annual flow \\
\hline Sardinia & $\begin{array}{l}\mathrm{MVF}=10 \%\left(\mathrm{Q}_{\mathrm{n}}\right)[\text { In use }] \\
\mathrm{MVF}=\mathrm{Qn}(\mathrm{t}, \mathrm{f}) \times \mathrm{K}[\text { Under experimentation }]\end{array}$ & $\begin{array}{l}\mathrm{Q}_{\mathrm{n}:} \text { natural flow } \\
\mathrm{Qn}(\mathrm{t}, \mathrm{f}) \text {; natural flow as a function of monthly mean rainfall } \\
\mathrm{K} \text { : coefficient related to hydro-morphological parameters }\end{array}$ \\
\hline
\end{tabular}


Decree 152/06. To overcome the above-highlighted issues, in 2017 the Italian Ministry of the Environment and Protection of the Territory and the Sea (MATTM) approved the Directorial Decree n. 30/STA (DD 30/STA hereafter), to update and provide homogeneous and scientifically advanced methodologies for the definition of the ecological outflow throughout the national territory, as requested by the European Commission (CIS Guidance Document n. 31/2015).

\section{IMPLEMENTATION OF HYDRAULIC-HABITAT SIMULATION MODELS IN ITALY}

Within the Italian territory, a variety of hydraulichabitat approaches have been tested to enhance the hydrological based e-flow assessments. The meso-scale or meso-habitat models were used in different Italian regions for several species of fish. The geomorphic unit (or mesohabitat) generally ranges between about $1 \mathrm{~m}$ and $100 \mathrm{~m}$ (Hauer et al., 2009; Parasiewicz et al., 2013). This resolution allows the use of a wide range of environmental variables for the description of the fluvial habitat, obtaining a biological analysis of the life cycle of a single species or several communities, such a fish (Gosselin et al., 2012; Wilkes et al., 2015). The mesohabitat scale approach includes habitat suitability criteria to identify habitat characteristics in relation with different water regimes needed for the presence of particular species, for a particular biologically relevant periods of the year (e.g., spawning), or for particular endangered or threatened species (Vezza et al., 2012). The MesoHABSIM model was used to describe habitat distribution and e-flow requirements needed to support local populations of the endangered White-clawed Crayfish (Austropotamobius pallipes) in Lombardy region and in the Gran Sasso and Laga National Park mountainous streams (Abruzzo region). With the use of a meso-habitat scale approach and time series analysis, detailed schemes of flow management were defined to represent habitat changes over time and to identify stress conditions for $A$. pallipes, created by the persistent limitations in habitat availability (Vezza et al., 2016). The habitat suitability model MesoHABSIM, based on the statistic models Random Forest and Logistic Regression, was also used to estimate habitat preferences for the bullhead fish (Cottus gobio) in Alpine streams (Vezza et al., 2014a). The distribution of bullhead fish in various habitat was also predicted with a MesoHABSIM model created with a deductive model, based on conditional habitat suitability criteria derived from expert knowledge and literature information (Adamczyk et al., 2019). Furthermore, the meso-habitat suitability model was used to quantify habitat alteration and to define e-flow schemes in high gradient streams using biological and hydro-morphological data from 40 study sites located within the mountainous areas of different regions, such as Aosta Valley, Piemonte and Liguria (Northwest Italy) (Vezza et al., 2014b). Moreover, the habitat meso-scale approach has been used to identify the optimal regime flow considering the limiting factors' approach and the assessment of basic ecological relationships. In a study conducted in the Serio River (Northern Italy), densityenvironmental variables relationships for three different life stages of the brown trout were investigated to select a range of flows able to preserve most of the physical habitat for all of the trout life stages. The results highlighted that the main factors limiting the trout densities were water velocity, substrate characteristics and availability of refugia from predation. This study also estimated the effect of varying discharge flows on macroinvertebrate biomass, and it was then used to identify an optimal flow maximizing either habitat and prey availability (Fornaroli et al., 2013). In the Aosta Valley (North-Western Italy), the indices of river habitat integrity derived from the MesoHABSIM methodology were also used to demonstrate that the application of meso-scale habitat models allows the assessment of hydro-morphological spatio-temporal alterations of habitat's structure and that these models and indices can be adequately integrated into a multi-criteria analysis framework, supporting decision-making processes by the competent authorities (Vassoney et al., 2019).

Another type of hydraulic-habitat methodologies for estimating the e-flow assessment relies on the microhabitat approach. Such an approach is used when the scale of investigation zooms in at site-specific or species-specific level, for example, when the focus switch on the conservation of one or few targeted species. This approach requires the acquisition of precise knowledge and data on the relationships between specific flow conditions and the life cycle requirements of the targeted species. Such data are essential to create Habitat Suitability Curves (HSC) and apply microhabitat-hydrological approaches to estimate a suitable e-flows tailored at the site-specific scale. However, in the literature, Habitat Suitability Curves are available only for a few species, and the availability of experimental curves on the Italian national territory is still very limited (Vismara et al., 2001). Another important limitation of the use of micro-habitat approaches is their dependence on hydraulic simulation models (1D or 2D), which are difficult to be used, or even inappropriate, in high gradient streams (Vezza et al., 2014), in intermittent streams (Acuña et al., 2020), in lowland macrophyte-dominated rivers (Hearne et al., 1994) and in rivers with winter ice (Alfredsen and Tesaker 2002). Experimental studies, using the microhabitat approach, have been mostly carried out to correct 
the suitability of flow regimes released by the Basin River Authorities' formulas for several target species. The micro-habitat methodology PHABSIM was used by the Marecchia-Conca Basin River Interregional Authority (Salmoiraghi and Morolli, 2007) to determine the value of the optimal flow needed to guarantee the functionality of the river system and the life of its organisms in several sections of the Marecchia River and its tributary Senatello (as a contribution to the Partial Basin Plan for the Hydrological Instability). This study provided evidence of the need to correct the e-flows previously established to ensure the optimal habitat availability for the trout (Salmo trutta), the barbel (Barbus plebejus), and the chub (Leuciscus cephalus) with those obtained from the application of the PHABSIM model. The micro-habitat approach, Instream Flow Incremental Methodology (IFIM, Bovee et al., 1998) was applied in the Taro River (Northern Italy) to estimate the e-flow for three fish species (Barbus plebejus, Chondrostoma genei and Leuciscus souffia) and their vital stages (young, adults and reproductive stage). Once again, the results highlighted how the value of the e-flow, adopted so far for the Taro river, calculated according to the general formula proposed by the Basin Authority for the Po river, did not guarantee the preservation of any of the species analyzed in the study case. The same study also determined two different flow thresholds for each species: a "Critical" threshold that indicates the flow in which species can "survive", and an "Ecological flow" threshold in which species can spend their life in a habitat favorable to their needs (Chiussi et al., 2009). Finally, microhabitat simulation using the PHABSIM software was used to estimate eflow requirements for salmonids and brown trout in the Cordevole river basin. This study case demonstrated that a fixed water release of $600 \mathrm{~L} \mathrm{~s}^{-1}$ could be sufficient for the maintenance of good quality habitat for salmons, whereas a water releases of at least $350 \mathrm{~L} \mathrm{~s}^{-1}$ is sufficient for the maintenance of a good quality condition for brown trout's habitat (Schmidt and Benítez Sanz, 2012). More recently, other models have used alternative approaches based on a mix of expert opinions and fuzzy logic-based rules to describe the habitat use by target species and for the application of hydraulic-habitat models. A modified IFIM micro-habitat method, using a fuzzy logic-based model, was applied to the barbel (Barbus plebejus) and the chub (Leuciscus cephalus) habitat suitability response to hydrologic and water quality parameters variation in the Arno and Serchio rivers. This trial provided evidence that fuzzy logicbased estimates of the target species' response to critical environmental variations are more reliable than those obtained through the conventional IFIM approach (Marsili-Libelli et al., 2013).

\section{E-FLOW IMPLEMENTATION IN SARDINIA (ITALY)}

Sardinia is the second largest island in the Mediterranean Sea. It is characterized by a typically Mediterranean climate with warm and moderately rainy winters and dry and hot summers. Sardinian rivers are characterized by a strong variability of the water outflow, due to seasonal hydrological oscillations (Gasith and Resh 1999; De Waele et al., 2010), and they constitute the predominant water contribution to the island water resources since the contributions from snowmelt and groundwater are almost negligible. In the last decades, a drastic mean yearly runoff decrease (up to ca $40 \%$ over the 1975-2010 period when compared with the previous 50 years; Montaldo and Sirigu, 2017) has been registered for Sardinian basins. This caused relevant water scarcity issues and led to the construction of more than 50 dams, to store water in critical periods of the year. Winter precipitations will reduce in the near future because of expected changes in the North Atlantic Oscillation (NAO) index associated with climate change (Montaldo and Sirigu, 2017). This will likely determine a further decrease of water resources availability in Sardinia, which, in turn, will require an increase in the number of hydro-morphologic alterations to satisfy the water demand for agriculture and human uses. Additionally, this scenario will also be exacerbated because of unpredictable extreme rainfalls, to which Sardinia is being more and more vulnerable. For example, in years from 2004 to 2018, these events became particularly frequent (at least once per year) and often produced flash floods causing severe changes in channel morphology and sediment distribution, damage to private and public infrastructure, and even human deaths (Bodini et al., 2010; De Waele et al., 2010).

Given the present and future critical scenario in rivers' runoff and their predictable strong impacts on freshwater habitats, new strategies and designs in water resources planning and management are required. This need appears crucial, especially for the assessment of a sustainable eflow regulation plan aimed at ensuring the maintenance of key (including endemic) habitats and species.

To date, the Sardinian Water Basin Management Plan simply requires the maintenance of a fixed MVF equal to the $10 \%$ of the natural flow regime (i.e., the natural water flow, excluding any withdraw or artificial input). However, in 2018, following the DD 30/STA, the regional Ecological Flows Resolution n.8/2018. This directive sets out a methodological approach for the determination of the e-flow in order to ensure the maintenance, in watercourses, of the ecological flow to support the achievement of environmental objectives defined in accordance with Directive 2000/60/EC. This directive updated the formula to estimate e-flow as follows: 


$$
E_{\text {flow }}=Q_{n}(t, f) \times K
$$

where $Q_{n}(t, f)$ is the water flow of the watercourse at its natural condition in the time $t$ as a function of the monthly average rainfall $f$, and $K$ is a coefficient calculated from the combined assessment of the current river ecological status, the analysis of the pressures affecting the river, and the hydro-morphological and biological parameters. According to the Directive n.8/2018, this new formula, and its hydro-morphological and biological parameters, has to be tested and validated with specific technicalscientific experimentation for the determination of site-specific e-flow values. Since none experimental application of hydraulic-habitat models have been tested in the Sardinian territory, this formula has been identified as the basis for a rapid, homogeneous district-scale e-flow implementation plan, coping with the large heterogeneity of eco-hydraulic conditions of the Sardinian rivers. In particular, the adoption in the formula of a rainfall-related coefficient, of patterns in flow regime at either intra- and inter-annual temporal scales and of correction coefficients considering hydro-morphological and biological targets is expected to allow the development of a more reliable and GES-oriented e-flow assessment, integrated into the WFD process.

\section{CHALLENGES AND LIMITATIONS}

E-flow science has evolved substantially in the last decades, with a growing number of experts involved to develop new approaches and methods to respond to the numerous challenges that the implementations of the eflow policy triggers (Acreman, 2016). However, despite the increasing number of published e-flow related studies, approaches, models, methods, and experimental applications to numerous locations, remain a global lack of achievement of appropriate e-flow assessment policy, mainly due to the conflicts arising between the preservation of the riverine environment and the management and exploitation of water resource for human needs (Le Quesne et al., 2010).

In Europe, considerable progress has been made on the application of the e-flow through the implementation of the Water Framework Directive (European Commission, 2015). The CIS Guidance Document No. 31 provided an important and useful tool for MSs to refine e-flow targets by developing new methods, spanning from relatively simple hydrologic to the highly sophisticated ones. However, significant challenges remain to achieve the ambitious objectives of the WFD, especially with regard to the e-flow assessment. Some of these challenges revolve around the integration of macro-scale considerations into regional and basin-scale integrated water management plans. In a context of changing society, increasing population and changing climate, the water flow governance has to be adapted to the territorial specificities, in terms of regulatory and institutional frameworks, cultural practices, climatic, geographical and economic conditions.

In Italy, the e-flow matter has been faced in a more concrete way only in recent years. The introduction of the DD 30 / STA in 2018 imposed to all the District Authorities a substantial change in the water management policies, in terms of the amount of outflow released downstream dams and weirs and the release of new water withdrawal concessions. This process led to move from a merely water management oriented MVF concept to another one oriented primarily at preserving the river ecosystems and maintain them in a Good Environmental Status. A more detailed approach is needed, as suggested by the DD 30/STA, to update the already available methods with new ones. A spatial downscaling process of e-flow assessment will require new quantitative and qualitative approaches involving a multidisciplinary panel of experts (e.g., engineers, hydrologists, hydraulic modellers, ecologists and socio-economists) but also a large effort to test, by an accurate monitoring plan, the reliability and efficacy of the estimated e-flow values in the field. Ideally, the process should become so accurate and reliable to allow a feedback monitoring approach, by which corrections to the e-flow will be adopted pending the availability of early warning indicators of environmental change. This approach, by cascade, will allow the design and operability of management measures able to correct any gap from the expected GES. This process, again, will need an accurate implementation of e-flow values and monitoring of its efficacy at the different spatial scales, from the regional to the basin one. This will require a huge effort in ameliorating the knowledge of biological and ecological processes sustaining the GES at the different spatial scales, which will require more and more commitments to either basic or applied research.

This, in our view, will hold true especially for the case of Sardinia, where the management of water resources is heavily dependent on the socio-economic and climate contexts. In a territory that has been suffering for the past ten years one of the most critical water scarcity conditions, numerous technical and logistical challenges will presumably arise. For example, the necessity of providing the needed water for agriculture, industrial or human usages insight of critical periods will likely push the authorities to never allow the release of a proper eflow. The need of different approaches to be adopted for very different rivers arises if we consider the plausible difficulties in establishing an e-flow value for intermittent or even ephemeral rivers (as the majority of those encountered in Sardinia) when compared with the 
perennial ones (Theodoropoulos et al., 2019). A critical issue for the application of e-flow, wherever defined and quantified, remains - peculiarly for the Sardinian territory - the limited infrastructural tools to manage waters' release from dams built in a time when e-flow was not considered at all and, therefore, which are not equipped, yet, with the technology able to operate in a reasonable time the needed water release in response to a change or decline in river ecosystem ecological integrity. Arguably, in the future, a scientifically grounded implementation of water management infrastructures embodying the e-flow concept will be needed in order to address also the potential societal implication of water management, especially where this will generate conflicts between economic and ecological sustainability targets.

In this context, hydraulic-habitat models can provide ecologically important data to calibrate hydrological methods and update e-flow release at different spatial and time scale within the Italian territory. In Italy, microhabitat approaches have been used mostly to correct minimum vital flow adopted in the River Basin Management Plans. These methodologies tailored e-flow assessment at the site-specific scale, mostly downstream dams and hydropower stations, for only a few fish species and their vital stages. This approach can be useful when there is the necessity of focusing on one endangered species or when dealing with a specific e-flow release situation. Nevertheless, due to their dependence on hydrological models, they are unreliable for low flow and non-flow periods. These limitations make this approach not well suitable for the definition of a regional or basinscale e-flow assessment, especially in a water-scarce region such as Sardinia. Differently, the application of meso-scale methodologies, in particular the MesoHABSIM method, results to be more suitable to the Italian territory as it can be adequately integrated into a multi-criteria analysis framework allowing the calculation of e-flow criteria from site-specific to the regional and basin-scale (Vezza et al., 2014; Parasiewicz et al., 2019). Furthermore, using deductive models, based on conditional habitat suitability criteria derived from expert knowledge and literature-based information, MesoHABSIM model can provide general information about habitat suitability even with a small amount of field data. Another important benefit of this approach, especially in a heterogeneous territory such as Italy, is the applicability of this model to different hydromorphological river types, allowing to describing complex habitat dynamics also in temporary rivers (Acuña et al., 2019) or where characteristics of the riverbed do not allow the use of hydraulic simulation models (Vassoney et al., 2019). In conclusion, we suggest that the meso-habitat approach result particularly appropriate for modelling and evaluating the integrity of rivers' habitats within the Italian territory, with the aims of defining the regional and basin e-flow assessment. It could be also used in monitoring e-flow release from catchments and dams and rivers requalification projects, as well as evaluating the impact of hydro-morphological pressure over fish fauna of watercourses and conserving particular protected aquatic species.

It is also worth to notice that the MesoHABSIM method uses an open-source software, which is reliable and traceable, and it expresses a judgement, through the habitat integrity index, which is divided into five classes, as for other indicators required by the European legislation. For the Italian territory, the set of models available for the MesoHABSIM methodology includes 24 fish species (and relative vital stages), typical of the Italian hydrographic system (SimStream software, referred to in MLG ISPRA 154/2017). However, this method has been applied mostly on northern regions, in order to further developed and improved the integration of this method for e-flow assessment within the Italian territory, is essential to conduct further field studies at local and regional scale to calibrate and validate habitat suitability index in different contexts and for different species. In particular, in the Sardinian region, insight of the high climate change-driven flow alterations predicted for the future scenario, the best science-based information of species response to habitat limitation will be required. We suggest that MesoHABSIM method should be implemented together with the validation of the recently proposed formula to obtain a solid and reliable e-flow assessment methodology. Today, more than ever, human actions in river ecosystems have become one of the primary contributions to the decline of freshwater habitats and species (Postel and Richter, 2003). Worldwide, maintaining ecosystem functions and services at current levels in a warmer climate and under changing socioeconomic conditions is a major challenge for water resources managers. Reducing pressures on water quality and maintenance of natural flow regimes are two of the main management actions that can help to ensure habitats conservation, at the same time favouring species resilience to flow alterations (Dudgeon et al., 2006). Thus, we further conclude that the definition of handling and reliable e-flow assessment methods embedding the expected consequences of natural and anthropogenic disturbance with the need of nature conservation is to be considered a basic priority of any water management plan.

\section{ACKNOWLEDGEMENTS}

This study has been carried out in the framework of a collaboration between the Head Office of the Regional Agency of the Sardinian River Basin District (Servizio Tutela e Gestione delle Risorse Idriche, Vigilanza sui 
Servizi Idrici e Gestione delle Siccità) and the Departments of Civil-Environmental Engineering and Architecture (DICAAR) and of Life and Environmental Sciences (DISVA) of the University of Cagliari, Italy.

Corresponding author: mocciadavide@unica.it

Key words: Ecological flow; minimum vital flow; Water Framework Directive; anthropogenic pressures; Italy; Sardinia.

Received: 23 Dicember 2019.

Accepted: 12 May 2020

This work is licensed under a Creative Commons Attribution NonCommercial 4.0 License (CC BY-NC 4.0).

${ }^{\circ}$ Copyright: the Author(s), 2020

Licensee PAGEPress, Italy

Advances in Oceanography and Limnology, 2020; 11:8781

DOI: 10.4081/aiol.2020.8781

\section{REFERENCES}

Acreman M, 2016. Environmental flows-basics for novices. WIREs Water 3:622-628.

Acreman MC, Dunbar MJ, 2004. Defining environmental river flow requirements - a review. Hydrol. Earth Syst. Sci. 8: 861-876.

Acreman M, Ferguson A, 2010. Environmental flows and the European water framework directive. Freshwater Biol. 55:32-48.

Acuña V, Jorda-Capdevila D, Vezza P, De Girolamo A.M, McClain ME, Stubbington R, Pastor AV, Lamouroux N, von Schiller D, Munné A, Datry T, 2020. Accounting for flow intermittency in environmental flows design. J. Appl. Ecol. 57:742-753.

Adamczyk M, Parasiewicz, P, Vezza P, Prus P, De Cesare G, 2019. Empirical validation of MesoHABSIM models developed with different habitat suitability criteria for bullhead Cottus Gobio L. as an indicator species. Water 11:726.

Alfredsen K, Tesaker E, 2002. Winter habitat assessment strategies and incorporation of winter habitat in the Norwegian habitat assessment tools. Hydrol. Process. 16:927-936.

Arthington AH, Bhaduri A, Bunn SE, Jackson SE, Tharme RE, Tickner D, Young B, Acreman M, Baker N, Capon S, Horne AC, Kendy E, McClain ME, Poff NL, Richter BD, Ward S, 2018. The Brisbane Declaration and Global Action Agenda on Environmental Flows (2018). Front. Envirn. Sci. 6:45.

Arthington AH, Tharme R, Brizga SO, Pusey BJ, Kennard MJ, 2004. Environmental flow assessment with emphasis on holistic methodologies, p. 37-65. In: R. Welcomm and T. Petr (eds.). Proceedings of the Second International Symposium on the Management of Large Rivers for Fisheries Volume II RAP Publication 2004/17, FAO Regional Office for Asia and the Pacific, Bangkok.

Arthington AH, Zalucki JM, 1998. Comparative evaluation of environmental flow assessment techniques: review of methods. Land and Water Resources Research and Development Corporation, Canberra.

Barnett TP, Adam JC, Lettenmaier DP, 2005. Potential impacts of a warming climate on water availability in snowdominated regions. Nature 438:303-309.

Blöschl G, Hall J, Parajka J, Perdigão RAP, Merz B, Arheimer B, Aronica T, Chirico GB, Bilibashi A, Bonacci O, Borga M, Čanjevac I, Castellarin A, Chirico GB, Claps P, Fiala K, Frolova N, Gorbachova L, Güll A, Hannaford J, Harrigan S, Kireeva M, Kiss A, Kjeldsen TR, Kohnová S, Koskela JJ, Ledvinka O, Macdonald N, Mavrova-Guirguinova M, Mediero L, Merz R, Molnar P, Montanari A, Murphy C, Osuch M, Ovcharuk V, Radevski I, Rogger M, Salinas JL, Sauquet R, Šraj M, Szolgay J, Viglione A, Volpi E, Wilson D, Zaimi K, Živković N, 2017. Changing climate shifts timing of European floods. Science 357:588-590.

Bodini A, Cossu QA, 2010. Vulnerability assessment of CentralEast Sardinia (Italy) to extreme rainfall events. Nat. Hazard. Heart. Sys. 10: 61-72.

Bovee KD, 1982. A guide to stream habitat analysis using the IFIM. US Fish and Wildlife Service Report FWS/OBS-82/ 26. Fort Collins, USA.

Bovee KD, Lamb BL, Bartholow JM, Stalnaker CB, Taylor J, Henriksen J, 1998. Stream habitat analysis using the instream flow incremental methodology. Information and technology Report USGS/BRD/ITR-1998-0004. Fort Collins, CO: U.S. Geological Survey-BRD.

Brunetti M, Colacino M, Maugeri M, Nanni T, 2001. Trends in daily intensity of precipitation in Italy from 1951 to 1996. Int. J. Climatol. 21:299-316.

Bunn SE, Arthington AH, 2002. Basic principles and ecological consequences of altered flow regimes for aquatic biodiversity. Environ. Manage. 30:492-507.

Caissie D, El-Jabi, 1995. Comparison and regionalization of hydrologically based instream flow techniques in Atlantic Canada. Can. J. Civ. Eng. 22:235-246.

Chiussi S, Bodini A, Bondavalli C, Pattini L, 2009. [Il caso del Fiume Taro (Provincia di Parma)].[Article in Italian]. Biologia Ambientale 23:56-65.

Coppola E, Giorgi F, 2010. An assessment of temperature and precipitation change projections over Italy from recent global and regional climate model simulations. Int. J. Climatol. 30:11-32.

De Girolamo AM, Bouraoui F, Buffagni A, Pappagallo G, Lo Porto A, 2017. Hydrology under climate change in a temporary river system: Potential impact on water balance and flow regime. River. Res. App. 33:1219-1232.

De Waele J, Martina MLV, Sanna L, Cabras S, Cossu QA, 2010. Flash flood hydrology in karstic terrain: Flumineddu Canyon, central-east Sardinia. Geomorphology 120:162-173.

Döll P, Fiedler K, Zhang J, 2009. Global-scale analysis of river flow alterations due to water withdrawals and reservoirs. Hydrol. Earth Syst. Sc. 13:2413-2432.

Dudgeon D, Arthington AH, Gessner MO, Kawabata ZI, Knowler DJ, Lévêque C, Naiman R, Prieur-Richard AH, Soto D, Stiassny MLJ, Sullivan CA, 2006. Freshwater biodiversity: importance, threats, status and conservation challenges. Biol. Rev. Camb. Philos. Soc. 81:163-82.

Dyson M, Bergkamp M, Scanlon J, 2003. Flow: The essentials of environmental flows. IUCN, Gland. 
E.E. Agency, Report n.7/2018. European waters - Assessment of status and pressures 2018.

Efstratiadis A, Tegos A, Varveris A, Koutsoyiannis D, 2014. Assessment of environmental flows under limited data availability: case study of the Acheloos River, Greece. Hydrolog. Sci. J. 5:731-750.

European Commission, 2015. Ecological flows in the implementation of the Water Framework Directive. WFD CIS Guidance Document No. 31.

Feyen L, Dankers R, 2009. Impact of global warming on streamflow drought in Europe. J. Geophys. Res. Atmos. 114:1-17.

Filipe AF, Lawrence JE, Bonada N, 2013. Vulnerability of stream biota to climate change in mediterranean climate regions: A synthesis of ecological responses and conservation challenges. Hydrobiologia 719:331-351.

Fornaroli R, Cabrini R, Sartori L, Marazzi F, Canobbio S, Mezzanotte V, 2016. Optimal flow for brown trout: Habitat - prey optimization. Sci. Total Environ. 566-567:1568-1578.

Forslund A, Renofält BM, Maijer K, Krchnak K, Cross K, Smith M, McClain M, Davidson S, Barchiesi S, Farrell T, 2009. Securing water for ecosystems and human well-being: The importance of environmental flows. Swedish Water House, Stockholm.

Galland J, 1991. TELEMAC: A new numerical model for solving shallow water equations. Adv. Water Resour. 14:138-148.

Gasith A, Resh VH, 1999. Streams in Mediterranean climate regions: Abiotic influences and biotic responses to predictable seasonal events. Annu. Rev. Ecol. Syst. 30:51-81

Giorgi F, 2006. Climate change hot-spots. Geophys. Res. Lett. 33:L08707.

Giorgi F, Lionello P, 2008. Climate change projections for the Mediterranean region. Global Planet. Change 63:90-104.

Gosselin MP, Maddock I, Petts G, 2012. Mesohabitat use by brown trout (Salmo trutta) in a small groundwaterdominated stream. River Res. Appl. 28:390-401.

Hauer C, Mandlburger G, Habersack H, 2009. Hydraulically related hydro-morphological units: description based on a new conceptual mesohabitat evaluation model (MEM) using LiDAR data as geometric input. River Res. Appl. 25:29-47.

Horne AC, O'donnell EL, Acreman M, Mcclain ME, Poff NL, Webb JA, Stewardson MJ, Bond NR, Richter B, Arthington AH, Tharme RE, Garrick DE, Daniell KA, Conallin JC, Thomas GA, Hart BT, 2017. Moving forward: the implementation challenge for environmental water management, p. 649-673. In: A.C. Horne, J.A. Webb, M. J. Stewardson, B. Richter and M. Acreman (eds.), Water for the environment: From policy and science to implementation and management. Academic Press, London.

Jowett I, 2010. Rhyhabsim-river hydraulic and habitat simulation software. Tech. Rep. Manual Version 5.0. NIWA.

International Commission on Large Dams 2007. World Register of Dams, Paris. Available from: www.icold-cigb.net

King JM, Brown C, 2006. Environmental flows: Striking the balance between development and resource protection. Ecol. Soc. 11:26.

King JM, Brown CA, Sabet H, 2003. A scenario-based holistic approach for environmental flow assessments. River Res. Appl. 19:619-639.
King JM, Louw MD, 1998. Instreamflow assessments for regulated rivers in South Africa using the Building Block Methodology. Aquat. Ecosyst. Health Manag. 1:109-124.

King JM, Tharme RE, De Villiers MS, 2008. Environmental flow assessments for rivers: Manual for the Building Block Methodology. WRC Report No TT 354/08. Cape Town:364.

Lake P, 2007. Flow-regulated disturbances and ecological response: floods and droughts. In: P.J. Wood, D.M. Hannah and J.P. Sadler (eds.), Hydroecology and eco-hydrology: Past, present and future. J. Wiley \& Sons Ltd., Chichester.

Le Quesne T, Kendy E, Weston D, 2010. The implementation challenge. Taking stock of government policies to protect and restore environmental flows. WWF (World Wide Fund for Nature) and TNC (The Nature Conservancy).

Lionello P, Abrantes F, Congedi L, Dulac F, Gacic M, Gomis D, Goodess C, Hoff H, Kutiel H, Luterbacher J, Planton S, Reale M, Schröder K, Struglia MV, Toreti A, Tsimplis M, Ulbrich U, Xoplaki E, 2012. Introduction: Mediterranean climate: background information, p. xxxv-xc. In: P. Lionello (ed.), The climate of the Mediterranean region. From the past to the future. Elsevier. doi: 10.1016/B978-0-12-416042-2.00012-4.

Maddock I, Bickerton M, Spence R, Pickering T, 2001. Reallocation of compensation releases to restore river flows and improve instream habitat availability in the upper derwent catchment, derbyshire, UK. Regul. Rivers-Res. Manage. 17:417-441.

Magilligan FJ, Nislow KH, 2005. Changes in hydrologic regime by dams. Geomorphology 71:61-78.

Marsili-Libelli S, Giusti E, Nocita A, 2013. A new instream flow assessment method based on fuzzy habitat suitability and large-scale river modelling. Environ. Modell. Softw. 41:27-38.

Montaldo N, Sarigu A, 2017. Potential links between the North Atlantic Oscillation and decreasing precipitation and runoff on a Mediterranean area. J. Hydrol. 553:419-437.

Nilsson C, Reidy CA, Dynesius M, Revenga C, 2005. Fragmentation and Flow Regulation of the World's Large River Systems. Science 308:405-408.

OECD, 2012. OECD Environmental Outlook to 2050: The consequences of inaction. Organisation for Economic Cooperation and Development, Paris.

Parasiewicz P, 2001. MesoHABSIM: a concept for application of instream flow models in river restoration planning. Fish. Res. 26:6-13.

Parasiewicz P, 2007. The MesoHABSIM model revisited. River Res. Appl. 23:893-903.

Parasiewicz P, Rogers JN, Vezza P, Gortazar J, Seager T, Pegg M, Wiśniewolski W, Comoglio C, 2013. Applications of the MesoHABSIM simulation model, p. 109-124. In: I. Maddock, P. Kemp and P. Wood (eds.), Ecohydraulics: an integrated approach. J. Wiley \& Sons Ltd., Chichester.

Parasiewicz P, Prus, P, Theodoropoulos, C, Alfredsen K, Adamczyk M, Comoglio C, Vezza P, 2019. Editorial: Environmental flows determination and monitoring with hydraulic habitat models - Pushing the boundaries of habitat models application. Water 11:1950.

Peñas FJ, Barquín J, Álvarez C, 2016. Assessing hydrologic alteration: Evaluation of different alternatives according to data availability. Ecol. Indic. 60:470-482.

Pletterbauer F, Melcher A, Graf W, 2018. Climate change 
impacts in riverine ecosystems, p. 203-223. In: S. Schmutz and J. Sendzimir (eds.), Riverine ecosystem management. Springer, Cham.

Poff NL, Allan JD, Bain MB, Karr JR, Prestegaard KL, Richter BD, Sparks RE, Stromberg JC, 1997. The natural flow regime. BioScience 47:769-784

Poff NL, Matthews JH, 2013. Environmental flows in the Anthropocence: past progress and future prospects. Curr. Opin. Env. Sust. 5:667-675.

Poff NL, Richter BD, Arthington AH, Bunn SE, Naiman RJ, Kendy E, Acreman M, Apse C, Bledsoe BP, Freeman MC, Henriksen J, Jacobson RB, Kennen JG, Merritt DM, O'Keeffe JH, Olden JD, Rogers K, Tharme RE, Warner A, 2010. The ecological limits of hydrologic alteration (ELOHA): a new framework for developing regional environmental flow standards. Freshwater Biol. 55:147-170.

Poff NL, Zimmerman JKH, 2010. Ecological responses to altered flow regimes: a literature review to inform the science and management of environmental flows. Freshwater Biol. 55:194-205.

Postel SL, 1998. Water for food production: Will there be enough in 2015. BioScience 48:629-637.

Postel S, Richter BD, 2003. Rivers for life: Managing water for people and nature, ecological economics. Island Press, Washington, DC.

Richter BD, 2009. Rethinking environmental flows: from allocations and reserves to sustainability boundaries. River Res. Appl. 26:1052-1063.

Richter BD, Warner AT, Meyer JL, Lutz K, 2006. A collaborative and adaptive process for developing environmental flow recommendations. River Res. Appl. 22:297-318.

Salmoiraghi G, Morolli C, 2007. [Aggiornamento ed integrazione attività di studio per la determinazione sperimentale dei valori di deflusso minimo vitale (DMV) per il fiume Marecchia].[Report in Italian]. Autorità di Bacino Interregionale Marecchia-Conca: 74 pp.

Schmidt G, Benítez Sanz C, 2012. Analysis of the implementation of environmental flows in the wider context of the river basin management plans. Technical Report. Available from: https:/ec.europa.eu/environment/archives/water/implrep2007 /pdf/Water\%20abstraction\%20and\%20use\%20-\%20Eflows. pdf

Schneider M, Jorde K, Zoellner F, Kerle F, 2001. Development of a user-friendly software for ecological investigations on river systems, integration of a fuzzy rulebased approach, $p$. 354-360. In: L.M. Hilty and P.W. Gilgen (eds.), Sustainability in the Information Society. Metropolis, Marburg.

Schneider M, Noack M, Gebler T, Kopecki I, 2010. Handbook for the habitat simulation model CASiMiR-fish. Base Version.

Spinoni J, Vogt JV, Naumann G, Barbosa P, Dosio A, 2017. Will drought events become more frequent and severe in Europe? Int. J. Climatol. 381718-1736.

Steffler P, Blackburn J, 2002. River 2D: Two-dimensional depth averaged model of river hydrodynamics and fish habitat. Introduction to Depth Averaged Modelling and User's Manual. University of Alberta.

Surian N, Rinaldi M, 2003. Morphological response to river engineering and management in alluvial channels in Italy. Geomorphology 50:307-326.
Tennant DL, 1976. Instream flow regimens for fish, wildlife, recreation and related environmental resources. Fisheries 1:6-10.

Tharme RE, 1996. Review of International Methodologies for the Quantification of the Instream Flow Requirements of Rivers. Water law review final report for policy development for the Department of Water Affairs and Forestry, Pretoria. Freshwater Research Unit, University of Cape Town.

Tharme RE, 2000. An overview of environmental flow methodologies, with particular reference to South Africa, $p$. 15-40. In: J.M. King, R.E. Tharme and M.S. De Villiers (eds.), Environmental Flow Assessments for Rivers: Manual for the Building Block Methodology. Water Research Commission Technology Transfer Report No. TT131/00. Water Research Commission: Pretoria.

Tharme RE, 2003. A global perspective on environmental flow assessment: emerging trends in the development and application of environmental flow methodologies for rivers. River Res. Appl. 19:397-441.

The Brisbane Declaration, 2007. Environmental flows are essential for freshwater ecosystem health and human wellbeing. Proceedings 10th Int. River Symp. and Int. Environ. Flows Conf., 2007, Brisbane. Available from: https://www.conservationgateway.org/ConservationPractice s/Freshwater/EnvironmentalFlows/MethodsandTools/ELO HA/Pages/Brisbane-Declaration.aspx

Theodoropoulos C, Papadaki C, Vardakas L, Dimitriou E, Kalogianni E, Skoulikidis N, 2019. Conceptualization and pilot application of a model-based environmental flow assessment adapted for intermittent rivers. Aquat. Sci. 81:10.

Tomozeiu R, Pasqui M, Quaresima S, 2017. Future changes of air temperature over Italian agricultural areas: a statistical downscaling technique applied to 2021-2050 and 20712100 periods. Meteorol. Atmos. Phys. 1-21.

Tonkin JD, Poff NL, Bond NR, Horne A, Merritt DM. Reynolds LV, Ruhi A, Lytle DA, 2019. Prepare river ecosystems for an uncertain future. Nature 570:301-303.

U.S. Geological Survey (USGS), 2001. PHABSIM user's manual.

Vassoney E, Mammoliti Mochet A, Rocco R, Maddalena R, Vezza P, Comoglio C, 2019. Integrating meso-scale habitat modeling in the multicriteria analysis (MCA) process for the assessment of hydropower sustainability. Water 11:640.

Vezza P, Ghia D, Fea G, 2016. Quantitative habitat models for the conservation of the endangered European crayfish Austropotamobius pallipes Complex (Astacoidea: Astacidae). In: T. Kawai and N. Cumberlidge (eds.), A global overview of the conservation of freshwater decapod crustaceans. Springer, Cham.

Vezza P, Parasiewicz P, Calles O, Spairani M, Comoglio C, 2014a. Modelling habitat requirements of bullhead (Cottus gobio) in Alpine streams. Aquat. Sci. 76:1-15.

Vezza P, Parasiewicz P, Rosso M, Comoglio C, 2012. Defining minimum environmental flows at regional scale: Application of mesoscale habitat models and catchments classification. River Res. Applic. 28:717-730.

Vezza P, Parasiewicz P, Spairani M, Comoglio C, 2014b. Habitat modelling in high-gradient streams: The mesoscale approach and application. Ecol. Appl. 24:844-861.

Viganò G, Confortola G, Fornaroli R, Cabrini R, Canobbio S, 
Mezzanotte V, Bocchiola D, 2016. Effects of future climate change on a river habitat in an italian alpine catchment. J. Hydrol. Eng. 21:1-14.

Vismara R, Azzellino A, Bosi R, Crosa G, Gentili G, 2001. Habitat suitability curves for brown trout (Salmo trutta fario L.) in the River Adda, Northern Italy: comparing univariate and multivariate approaches. Regul. River. 17:37-50.

Wilkes MA, Maddock I, Link O, Habit E, 2015. A communitylevel, mesoscale analysis of fish assemblage structure in shoreline habitats of a large river using multivariate regression trees. River Res. Appl. 32:652-665.

Zang CF, Liu J, van der Velde M, Kraxner F, 2012. Assessment of spatial and temporal patterns of green and blue water flows under natural conditions in inland river basins in Northwest China. Hydrol. Earth Syst. Sci. 16:2859-2870.

Zhang Q, Gu X, Singh VP, Chen X, 2015. Evaluation of ecological instream flow using multiple ecological indicators with consideration of hydrological alterations. J. Hydrol. 529:711-722. 